2001s-16

\title{
Marriage Market, Divorce Legislation and Household Labor Supply
}

Pierre-André Chiappori, Bernard Fortin, Guy Lacroix

\begin{tabular}{c}
\hline Série Scientifique \\
Scientific Series
\end{tabular}

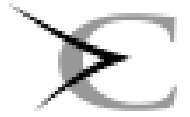




\section{CIRANO}

Le CIRANO est un organisme sans but lucratif constitué en vertu de la Loi des compagnies du Québec. Le financement de son infrastructure et de ses activités de recherche provient des cotisations de ses organisationsmembres, d'une subvention d'infrastructure du ministère de la Recherche, de la Science et de la Technologie, de même que des subventions et mandats obtenus par ses équipes de recherche.

CIRANO is a private non-profit organization incorporated under the Québec Companies Act. Its infrastructure and research activities are funded through fees paid by member organizations, an infrastructure grant from the Ministère de la Recherche, de la Science et de la Technologie, and grants and research mandates obtained by its research teams.

\section{Les organisations-partenaires / The Partner Organizations}

•École des Hautes Études Commerciales

-École Polytechnique

-Université Concordia

-Université de Montréal

-Université du Québec à Montréal

-Université Laval

-Université McGill

-MEQ

-MRST

-Alcan inc.

-AXA Canada

-Banque du Canada

- Banque Laurentienne du Canada

-Banque Nationale du Canada

-Banque Royale du Canada

-Bell Québec

-Bombardier

-Bourse de Montréal

-Développement des ressources humaines Canada (DRHC)

-Fédération des caisses populaires Desjardins de Montréal et de l'Ouest-du-Québec

-Hydro-Québec

-Imasco

-Industrie Canada

-Pratt \& Whitney Canada Inc.

-Raymond Chabot Grant Thornton

-Ville de Montréal

(C) 2001 Pierre-André Chiappori, Bernard Fortin et Guy Lacroix. Tous droits réservés. All rights reserved. Reproduction partielle permise avec citation du document source, incluant la notice $\odot$.

Short sections may be quoted without explicit permission, if full credit, including $\odot$ notice, is given to the source.

Ce document est publié dans l'intention de rendre accessibles les résultats préliminaires de la recherche effectuée au CIRANO, afin de susciter des échanges et des suggestions. Les idées et les opinions émises sont sous l'unique responsabilité des auteurs, et ne représentent pas nécessairement les positions du CIRANO ou de ses partenaires.

This paper presents preliminary research carried out at CIRANO and aims at encouraging discussion and comment. The observations and viewpoints expressed are the sole responsibility of the authors. They do not necessarily represent positions of CIRANO or its partners. 


\title{
Marriage Market, Divorce Legislation and Household Labor Supply ${ }^{*}$
}

\author{
Pierre-André Chiappori ${ }^{\dagger}$, Bernard Fortin ${ }^{\ddagger}$, Guy Lacroix ${ }^{\S}$
}

\section{Résumé / Abstract}

Cet article présente un cadre théorique visant à analyser l'impact du marché du mariage et des règles de divorce sur l'offre de travail du ménage. Dans notre approche, l'importance relative des hommes sur le marché du mariage ainsi que les lois régissant le divorce sont des exemples de «facteurs de distribution ». Ceux-ci sont définis comme étant des variables qui influencent le pouvoir de négociation des conjoints mais n'ont pas d'effet sur les préférences individuelles ni sur l'ensemble de consommation du ménage. Nous généralisons le modèle d'offre de travail collectif de Chiappori $(J P E, 1992)$ de façon à tenir compte des facteurs de distribution. Nous montrons que notre modèle impose de nouvelles restrictions sur les fonctions d'offre de travail des conjoints et facilite l'identification des préférences individuelles ainsi que le processus de décision intra-familial. Le modèle est estimé par la méthode des moments généralisés à l'aide des données du PSID pour 1988. Nos résultats ne rejettent pas les restrictions imposées par notre approche. De plus, l'importance relative des hommes de même que les règles de divorce jugées favorables aux femmes influencent les comportements d'offre de travail et le processus de décision dans les directions prédites par la théorie et jouent un rôle important dans les choix du ménage.

This paper provides a theoretical framework for analyzing the impact of the marriage market and divorce legislation on household labor supply. In our approach, the sex ratio on the marragie market and the rules governing divorce are examples of "distribution factors". The latter are defined as variables that affect the household members' bargaining position but neither preferences nor the

\footnotetext{
* Corresponding Author: Bernard Fortin, CIRANO, 2020 University Street, 25 ${ }^{\text {th }}$ floor, Montréal, Qc, Canada H3A 2A5 Tel.: (514) 985-4000 Fax: (514) 985-4039 email: bernard.fortin@ecn.ulaval.ca Forthcoming, Journal of Political Economy. This research received financial support from le fonds FCAR, the Social Sciences and Humanities Research Council of Canada, the NSF (grant SBR9729559) and l'École des hautes études en sciences sociales. This paper was partly written while Fortin and Lacroix were visiting DELTA, whose hospitality and financial support are gratefully acknowledged. We thank Simon Drolet and Philippe Belley for able research assistance. We are also grateful to Gary Becker, Martin Browning, Olivier Donni, Chris Flynn, Shoshana Grossbard-Shechtman, James Hackman, Derek Neal, Robert Pollak, Sherwin Rosen, Mark Rosenzweig, Wilbert Van der Klauuw, Frances Woolley, a referee and participants in many seminars for useful comments on an earlier version.

$\dagger$ University of Chicago

¥ Université Laval et CIRANO

$\S$ Université Laval et CIRANO
} 
joint budget set. We extend the collective labor supply model developped by Chiappori (JPE, 1992) to allow for distribution factors. We show that our model imposes new restrictions on the labor supply functions and eases the identification of individual preferences and the intra-household decision process. The model is estimated using PSID data for the year 1988. Our results do not reject the restrictions imposed by the model. Also, the sex ratio and divorce laws deemed favorable to women are found to impact the labor supply behavior and the decision process in the directions predicted by the theory and to have sizeable effects.

Mots Clés : Modèle collectif, offre de travail du ménage, marché du mariage, lois du divorce

Keywords: Collective model, household labor supply, marriage market, divorce laws

JEL: J12, J22, D7, D10 


\section{Introduction}

Does household behavior depend on the relative bargaining strength of each spouse? During the last decade, this question has attracted renewed attention from both empirical and theoretical analysts. On the empirical side, several papers have analyzed the behavioral impact of variables that may influence the intra-household distribution of power. For instance, Thomas (1990) and Browning et al. (1994) have provided evidence that the distribution of total intra-household income has a significant impact on outcomes, thus rejecting the standard "income pooling" prediction. More recently, Thomas et al. (1997), using an Indonesian survey, have shown that the distribution of wealth by gender at marriage has a significant impact on children health in those areas where wealth remains under the contributor's control ${ }^{1}$. Duflo (1999) has derived related conclusions from a careful analysis of a reform of the South African social pension program that extended the benefits to a large, previously not covered black population. ${ }^{2}$

Relative incomes, however, are not the only possible variables that may affect the intra-household decision process. The latter can also depend on a range of variables that change the household's environment and in particular the members' respective bargaining positions. Factors that affect opportunities of spouses outside marriage can influence the intra-household balance of power, and ultimately the final allocation of resources, even when the marriage does not actually dissolve (a point already emphasized by Haddad and Kanbur 1992). Variables that proxy the situation in the marriage market are natural examples of these factors. This intuition can be traced back to Becker (1991, ch.3), who emphasized that the marriage market is an important determinant of intra-household utility distribution. In his approach, the state of the marriage market crucially depends on the sex ratio, that is, the relative supplies of males and females in the marriage market. When the sex ratio is favorable to the wife - i.e., there is a relative scarcity of women - then the distribution of gains from marriage will be shifted in her favor. This may in turn affect intra-household decisions. Using U.S. data at both the household level and the aggregate level, Grossbard-Shechtman (1993) and GrossbardShechtman and Neideffer (1997) found that an increase in the sex ratio reduces the labor force participation of married women and their hours worked. Angrist (2000) uses data on immigrants to the U.S. and similarly finds that higher sex ratios are associated with

\footnotetext{
${ }^{1}$ See also Galasso (1999) for a similar investigation.

${ }^{2}$ Specifically, Duflo finds that the consequences of this windfall gain on child nutrition dramatically depends on the gender of the recipient. Using the same data base, Bertrand et al. (2000) study the impact on labor supply of younger women within the household, and find again that the new benefits result in a much larger reduction of labor supply when they are received by a woman.
} 
lower female labor force participation.

Legislation may also play a role in the decision process. Laws governing the right to divorce, child support and marital property upon divorce influence the assignment of property rights between spouses, when a marriage ends. Therefore, they will affect the spousal relative bargaining positions and redistribution within marriage, at least to the extent that divorce matters as an outside opportunity. In a recent paper, Gray (1998) relates changes in female labor supply to the adoption of unilateral-divorce laws ${ }^{3}$ in many states during the 1970's. Using various data sources, and exploiting the legal changes that took place between two particular years, he finds a significant impact, when marital-property laws are controlled for. ${ }^{4}$ In a related way, Rubalcava and Thomas (2000) argue that variations in AFDC (Aid to Families with Dependent Children) across states directly affect the "reservation welfare" a spouse may be able to achieve in case of divorce.

Together, these empirical investigations very strongly suggest that intra-household bargaining has a significant impact on behavior, and should be analyzed with care. A striking fact, however, is that most of these works are not explicitly grounded in a structural model. ${ }^{5}$ For that reason, the interpretation of their empirical results is not straightforward. Of course, they certainly suggest that intra-household decision making is more complex than implied by the traditional, "unitary" model, based on the fiction of a single household utility that is maximized under budget constraint. However they do not say much on the true nature of the actual process.

On the theoretical side, various contributions have tried to introduce alternative frameworks in which intra-household decision processes can be adequately investigated.

\footnotetext{
${ }^{3}$ Unilateral-divorce laws specify that either spouse can initiate divorce. By contrast, mutual-consent laws require either the agreement of both spouses or the demonstration of marital fault.

${ }^{4}$ Divorce laws could also affect married women's labor supply through their effects on the risk of divorce. For instance, it is often argued that unilateral divorce encourages divorce by reducing its cost for the spouse who considers this option. However, empirical evidence does not generally support this view (e.g., Peters 1986, Gray 1998). While Friedberg (1998) finds that the adoption of unilateral divorce laws in U.S. during the "no-fault revolution" increased the divorce rates, this effect seems to disappear after a decade (Stevenson and Wolfers 2000). These results are in line with the Coase theorem, at least in the long run. This theorem asserts that changes in divorce laws should not affect efficiency in marriage and hence the divorce rates, as long as there are symmetry of information and trivial bargaining costs within marriage (Becker 1991).

${ }^{5}$ Grossbard-Shechtman and Neideffer (1997) have developed a choice-theoretic model of married women's labor supply in which the reservation wage depends on marriage market conditions. However their empirical analysis is based on a reduced form model that does not take into account the restrictions imposed by their structural model.
} 
Manser and Brown (1980) and McElroy and Horney (1981) have proposed models based on cooperative game theory. These attempts have been generalized by Chiappori (1988), Bourguignon et al. (1993), Browning and Chiappori (1998) and Chiappori and Ekeland (2001), who have developed a "collective" framework. In its most general version, the collective approach relies on the sole assumption that household decisions are Pareto efficient. It thus nests all model based on cooperative bargaining, at least under symmetric information. It can be proved that this minimal setting is sufficient to generate strong testable restrictions on behavior. Under additional restrictions, the collective model allows furthermore to identify the characteristics of the underlying structural model (i.e., individual preferences and the decision process) from observed behavior.

While the collective model provides an appealing theoretical framework to analyze household behavior, it needs to be generalized to take into account variables that, as discussed above, may affect the distribution of intra-household power. The first goal of the present paper is to fill this gap. The starting point of our analysis is the concept of "distribution factors" (Browning and Chiappori 1998). The latter are defined as variables that can affect the intra-household decision process without influencing individual preferences or the joint consumption set. The sex ratio is a natural example of a distribution factor. Divorce laws can also be regarded as distribution factors insofar as they influence outcomes only through their impact on spousal bargaining within marriage. Other examples of distribution factors include the share of total nonlabor income under the control of one spouse ${ }^{6}$ and special features of the marriage contracts. For instance, Lundberg and Pollak (1996) insist on whether marriage agreements are binding or not as a determinant of intra-household decision process. ${ }^{7}$

In this paper, we theoretically investigate and empirically estimate the effects of distribution factors in the context of a structural, micro-economic model of household behavior. The underlying intuition is quite simple. Whenever the distribution factor under consideration - say, the sex ratio - is favorable to one member - say, female are more scarce, which presumably increases the wife's bargaining position within the household then the respective weights in the decision process will be shifted in her favor. Standard income effects should, all else equal, lead to a reduction in female labor supply and an increase in male labor supply. The main purpose of our model is to provide a clean theoretical framework in which this idea can be worked out, and to point out the various restrictions that an explicit model of the household decision process imposes on behavior.

\footnotetext{
${ }^{6}$ One must reckon that these variables may raise delicate endogeneity problems. For instance, variations in nonlabor income over a cross-section are likely to be correlated with other (unobservable) determinants of household decisions (Behrman, Pollak and Taubman 1995).

${ }^{7}$ Unfortunately, it is difficult to construct empirical measures of these features.
} 
To do so, we extend various versions of the collective model by introducing distribution factors. First, we consider the most general collective framework, where each agent's utility is allowed to depend on both member's consumptions and labor supplies; in other words, the model allows for intra-household externalities of any kind (including public goods). In the absence of distribution factors, results by Browning and Chiappori (1998) and Chiappori and Ekeland (2001) imply that a three-commodity model like the one used here cannot generate testable restrictions on behavior. We show however that in the presence of at least two distribution factors, the collective model, even in its most general form, strongly restricts the form of labor supply ${ }^{8}$.

In its most general version, however, the collective model is not uniquely identified. For that reason, we next concentrate on the particular collective model of labor supply introduced by Chiappori (1992). The identifying assumption, here, is that household members have egotistic or Beckerian "caring" preferences (Becker 1991). The latter preferences allow for altruistic utility interdependence but impose weak separabillity between goods consumed by a household member and those consumed by his or her spouse. Efficiency has, in this setting, a very simple interpretation: household decisions can be modeled as a two-step process, whereby individuals first share their total nonlabor income according to some sharing rule, then maximize their own utilities subject to separate budget constraints. In particular, the intra-household decision process can be fully summarized by the sharing rule. We extend this model by allowing the sharing rule to depend on the various distribution factors under consideration as well as on wages and nonlabor income. We show that the main properties of Chiappori's initial model are preserved. In particular, it is still possible to identify individual preferences (up to a translation) and the sharing rule (up to an additive constant) from the sole observation of labor supply. Furthermore, the new context allows for a different identification procedure that is both simpler and more robust than before. It follows that the impact of distribution factors on behavior (if any) can in this context be given a direct interpretation in terms of intra-household transfers, and the welfare consequences can readily be assessed.

The presence of distribution factors also generates new testable predictions. For instance, in addition to the general restrictions evoked above, the theory imposes a close relationship between the effect of any distribution factor and the impact of cross wages on labor supply. These predictions are very unlikely to be fulfilled unless the model at

\footnotetext{
${ }^{8} \mathrm{~A}$ related result was already mentioned in Bourguignon, Browning and Chiappori (1995), although not in the context of labor supply. For empirical confirmation, see for instance Browning et al. (1994) and Thomas et al. (1997).
} 
stake is correct, which provides a rather strong test of our approach.

The final contribution of the paper is to estimate and test our collective model with the sex ratio and a "Divorce Laws Index" as distribution factors. The sex ratio we use is computed by age, race and state of residence. Our Divorce Laws Index, which is an indicator of the extent to which the laws are likely to be favorable to women, is also specific to the state of residence. While most papers that have analyzed the various behavioral effects of divorce laws have focused on one or two of them, we specifically take into account the four following features: mutual consent vs unilateral, property division, enforcement of support orders, and spousal interest in professional degrees and licenses. The availability of two distribution factors allows us to test not only the collective model with private goods but also the general version with externalities of any kind.

Our sample is drawn from Wave XXII of the PSID (1989 interview year) and focuses on couples in which both spouses work. We find that both the sex ratio and the divorce laws affect the spouses' labor supply in exactly the manner predicted by the theory. The parametric constraints associated with both versions of the model are not statistically rejected. Finally, the parameters of the sharing rule are recovered. According to these, changes in the sex ratio and in the Divorce Laws Index have sizeable impacts on income transfers within the households.

The structure of the paper is as follows. Section 2 presents our theoretical framework. Section 3 discusses the choice of the empirical specification used for estimation and testing. Section 4 describes our empirical strategy. Data and econometric results are discussed in Section 5. Finally, Section 6 concludes the paper.

\section{The Model}

\subsection{The basic setting}

In this section, we develop a collective labor supply model which takes into account distribution factors. In this framework, the household consists of two individuals with distinct utility functions and the decision process, whatever its true nature, leads to Pareto-efficient outcomes. This assumption seems quite natural, given that spouses usually know each other's preferences pretty well (at least, after a certain period of time) and interact very often. Therefore, they are unlikely to leave Pareto-improving 
decisions unexploited. ${ }^{9}$

A general framework Formally, let $h^{i}$ and $C^{i}$, for $i=1,2$, denote respectively member $i$ 's labor supply (with $0 \leq h^{i} \leq 1$ ) and consumption of a private Hicksian composite good whose price is set to unity. We start from the most general version of the model, in which member $i$ 's welfare can depend on his or her spouse's consumption and labor supply in a very general way, including for instance altruism, public consumption of leisure, positive or negative externalities, etc. In this general framework, member $i$ 's preferences are represented by some utility function $U^{i}\left(1-h^{1}, C^{1}, 1-h^{2}, C^{2}, z\right)$. Here, $z$ is a $K$-vector of preference factors, such as age and education of the two agents. Also, let $w_{1}, w_{2}, y$ denote respective wage rates and household nonlabor income. Finally, let $s$ denote a $L-$ vector of distribution factors.

Under the collective framework, intra-household decisions are Pareto-efficient. For any given $\left(w_{1}, w_{2}, y, z, s\right)$, hence, there exists a weighting factor $\mu\left(w_{1}, w_{2}, y, z, s\right)$ belonging to $[0,1]$, and such that the $\left(h^{i}, C^{i}\right)$ solves the following program:

$$
\begin{gathered}
\max _{\left\{h^{1}, h^{2}, C^{1}, C^{2}\right\}} \mu U^{1}+(1-\mu) U^{2} \\
\text { subject to } \\
w_{1} h^{1}+w_{2} h^{2}+y \geq C^{1}+C^{2}, \\
0 \leq h^{i} \leq 1, \quad i=1,2,
\end{gathered}
$$

where the function $\mu$ is assumed continuously differentiable in its arguments. It should thus be clear that the particular location of the solution on the Pareto frontier depends on all relevant parameters, since the value of $\mu$ depends on $w_{1}, w_{2}, y, z$ and $s$. Furthermore, since the vector of distribution factors, $s$, appears only in $\mu$, a change in $s$ does not affect the Pareto frontier but only the final location on it. In the particular case where $\mu$ is assumed to be constant, the collective framework corresponds to the unitary model with weakly separable household preferences. In this situation, the distribution factors have no effect on behavior.

In this general setting and assuming interior solutions, a first testable restriction arises on labor supplies. This restriction is given by the following result:

\footnotetext{
${ }^{9}$ However, see Udry (1996).
} 
Proposition 1 (Bourguignon, Browning and Chiappori 1995) Let $h^{i}\left(w_{1}, w_{2}, y, z, s\right), i=$ 1,2 be solutions to program $\left(\bar{P}^{1}\right)$. Then

$$
\frac{\partial h^{1} / \partial s_{k}}{\partial h^{1} / \partial s_{1}}=\frac{\partial h^{2} / \partial s_{k}}{\partial h^{2} / \partial s_{1}}, \quad \forall k=2, \ldots, L .
$$

Proof. For any fixed $\mu, h^{1}$ and $h^{2}$, as functions of $w_{1}, w_{2}, y$ and $\mu$, are well behaved Marshallian labor supplies. In particular, one gets

$$
h^{i}\left(w_{1}, w_{2}, y, z, s\right)=H^{i}\left(w_{1}, w_{2}, y, z, \mu\left(w_{1}, w_{2}, y, z, s\right)\right), \quad i=1,2,
$$

so that

$$
\begin{aligned}
\frac{\partial h^{i}}{\partial s_{j}} & =\frac{\partial H^{i}}{\partial \mu} \frac{\partial \mu}{\partial s_{j}} \\
& \text { and } \\
\frac{\partial h^{i} / \partial s_{k}}{\partial h^{i} / \partial s_{1}} & =\frac{\partial \mu / \partial s_{k}}{\partial \mu / \partial s_{1}} \text { is independent of } i .
\end{aligned}
$$

The basic intuition, here, is that distribution factors affect consumption and labor supply choices only through the location chosen on the Pareto frontier, or equivalently, through the implicit weighting of each spouse's utility. Since this weighting is unidimensional, this implies that the ratio of the impacts of all distribution factors on the two labor supplies are equal. It is worth stressing that these restrictions appear only when there are at least two distribution factors. If it is the case, they provide a test for Pareto efficiency in a general collective model of labor supply. Recent results by Chiappori and Ekeland (2001) imply that these conditions are also sufficient.

Egotistic preferences It should however be emphasized that this general version of the collective model cannot be uniquely identified from the sole knowledge of labor supplies. There are a continuum of different structural models which are observationally equivalent, i.e., which generate identical labor supply functions. Therefore, in our empirical analysis, we also estimate and test a model which imposes additional identifying assumptions. For now we will assume the following: 
Assumption $E$ ("egotistic preferences") Individual utilities are of the form $U^{i}(1-$ $\left.h^{i}, C^{i}, z\right)$, where $U^{i}$ is strictly quasi-concave, increasing and continuously differentiable, for $i=1,2$.

According to Assumption E, household members have egotistic preferences in the sense that the welfare of member $i$ does not depend on the consumption of member $j \neq i .{ }^{10}$ The corresponding model without distribution factors has been studied by Chiappori (1992). A first result, that can readily be extended to our framework, is that under Assumption E, efficiency has a very simple interpretation. Indeed, consider the household as a two-person economy. From the second fundamental welfare theorem, any Pareto optimum can be decentralized in an economy of this kind. Specifically, we have the following result:

Proposition 2 Under Assumption E, program $\left(\bar{P}^{1}\right)$ is equivalent to the existence of some function $\phi\left(w_{1}, w_{2}, y, z, s\right)$ such that each member $i(i=1,2)$ solves the program:

$$
\begin{aligned}
\max _{\left\{h^{i}, C^{i}\right\}} U^{i}\left(1-h^{i}, C^{i}, z\right) \\
\text { subject to } \\
w_{i} h^{i}+\phi^{i} \geq C^{i}, \\
0 \leq h^{i} \leq 1,
\end{aligned}
$$

where $\phi^{1}=\phi$ and $\phi^{2}=y-\phi$.

Proof. See Chiappori (1992).

The interpretation is that the decision process can always be considered as a two stage process : first, nonlabor income is allocated between household members and then, each member separately chooses labor supply (and private consumption), subject to the corresponding budget constraint. The function $\phi$ is called the sharing rule. It describes the way nonlabor income is divided up, as a function of wages, nonlabor income, distribution factors and other observable characteristics. ${ }^{11}$

\footnotetext{
${ }^{10}$ However our approach can be extended at basically no cost to "caring" preferences, where each person's utility depends on both his or her subutility index and on his or her spouse's (see below).

${ }^{11}$ In the presence of household public goods, a sharing rule can still be defined but conditionally on the level of these.
} 


\subsection{Restrictions on Labor Supplies and the Sharing Rule}

The collective framework with egotistic preferences imposes certain restrictions on the labor supply functions. To show this, let us first assume that the unrestricted labor supply functions $h^{i}\left(w_{1}, w_{2}, y, z, s\right)$ are continuously differentiable. From $\left(\bar{P}^{2}\right)$, and assuming interior solutions, these functions can be written as:

$$
\begin{gathered}
h^{1}=H^{1}\left(w_{1}, \phi\left(w_{1}, w_{2}, y, s, z\right), z\right), \\
h^{2}=H^{2}\left(w_{2}, y-\phi\left(w_{1}, w_{2}, y, s, z\right), z\right) .
\end{gathered}
$$

where $H^{i}(\cdot)$ is member $i$ 's Marshallian labor supply function.

The particular structure of equations (1) and (2) imposes testable restrictions on labor supply behavior and allows to recover of the partials of the sharing rule. It is important to note that, in contrast with the previous result, one distribution factor is sufficient for these conclusions to hold. The intuition goes as follows. Consider a change in, say, member 1's wage rate. This can only have an income effect on his or her spouse's behavior through its effect on the sharing rule, just as nonlabor income and the distribution factor. Thus, the impact of these variables on labor supply behavior of member 1 allows us to estimate the marginal rate of substitution between $w_{2}$ and $y$ as well as between $s$ and $y$ in the sharing rule. Technically, it generates two equations involving the corresponding partials of the sharing rule. The same argument applies to member 2's behavior, which leads to two other equations. These four equations allow to directly identify the four partials of the sharing rule. Finally, cross-derivative constraints on the sharing rule imposes restrictions to the model that can be tested.

To be more precise, using equations (1) and (2), define $A=h_{w_{2}}^{1} / h_{y}^{1}, B=h_{w_{1}}^{2} / h_{y}^{2}$, $C_{l}=h_{s_{l}}^{1} / h_{y}^{1}$ and $D_{l}=h_{s_{l}}^{2} / h_{y}^{2}$, whenever $h_{y}^{1} \cdot h_{y}^{2} \neq 0$, for $l=1, \cdots, L$. Note that all these variables are observable and can thus be estimated. Then one has the following results (where the subscript $l=1$ has been removed for notational convenience:

Proposition 3 Take any point such that $h_{y}^{1} \cdot h_{y}^{2} \neq 0$. Then

(i) If there exists exactly one distribution factor, and it is such that $C \neq D$, the following conditions are necessary for any pair $\left(h^{1}, h^{2}\right)$ to be solutions of $\left(\bar{P}^{2}\right)$ for some sharing rule $\phi$ :

$$
\frac{\partial}{\partial s}\left(\frac{D}{D-C}\right)=\frac{\partial}{\partial y}\left(\frac{C D}{D-C}\right)
$$




$$
\begin{gathered}
\frac{\partial}{\partial w_{1}}\left(\frac{D}{D-C}\right)=\frac{\partial}{\partial y}\left(\frac{B C}{D-C}\right) \\
\frac{\partial}{\partial w_{2}}\left(\frac{D}{D-C}\right)=\frac{\partial}{\partial y}\left(\frac{A D}{D-C}\right) \\
\frac{\partial}{\partial w_{1}}\left(\frac{C D}{D-C}\right)=\frac{\partial}{\partial s}\left(\frac{B C}{D-C}\right) \\
\frac{\partial}{\partial w_{2}}\left(\frac{C D}{D-C}\right)=\frac{\partial}{\partial s}\left(\frac{A D}{D-C}\right) \\
\frac{\partial}{\partial w_{2}}\left(\frac{B C}{D-C}\right)=\frac{\partial}{\partial w_{1}}\left(\frac{A D}{D-C}\right) \\
h_{w_{1}}^{1}-h_{y}^{1}\left(h^{1}+\frac{B C}{D-C}\right)\left(\frac{D-C}{D}\right) \geq 0 \\
h_{w_{2}}^{2}-h_{y}^{2}\left(h^{2}-\frac{A D}{D-C}\right)\left(-\frac{D-C}{C}\right) \geq 0 .
\end{gathered}
$$

(ii) Assuming that conditions $(2 a)-(2 h)$ hold and for a given $z$, the sharing rule is defined up to an additive function $\kappa(z)$ depending only on the preference factors $z$. The partial derivatives of the sharing rule with respect to wages, nonlabor income and the distribution factor are given by:

$$
\begin{aligned}
\phi_{y} & =\frac{D}{D-C} \\
\phi_{s} & =\frac{C D}{D-C} \\
\phi_{w_{1}} & =\frac{B C}{D-C} \\
\phi_{w_{2}} & =\frac{A D}{D-C} .
\end{aligned}
$$

If there are several distribution factors $(l=1, \cdots, L)$, an additional set of necessary and sufficient conditions are:

$$
\frac{C_{l}}{D_{l}}=\frac{C_{1}}{D_{1}}, \quad l=2, \cdots, L
$$

Moreover, the partial derivatives of the sharing rule with respect to the additional distribution factors are given by: 


$$
\phi_{s_{l}}=\frac{C_{l} D_{l}}{D_{l}-C_{l}}, \quad l=2, \cdots, L
$$

Proof. See Appendix.

These results suggest three remarks.

1. Conditions $(2 a)-(2 h)$ are analogous to Slutsky restrictions in the (general) sense that they provide a set of partial differential equations and inequalities that must be satisfied by the labor supply functions in order to be consistent with the collective model. It is important to note, in particular, that these conditions do not rely on any particular assumption on the functional form of preferences. Of course, the empirical test of these predictions is greatly simplified by the use of specific functional forms, as it will be the case below. But, in principle, the nature of the restrictions is non parametric. ${ }^{12}$

2. The form of the conditions above is quite different from those obtained in Chiappori (1992) for a similar model without distribution factors. As a matter of fact, the introduction of distribution factors deeply changes the way the model is identified. In Chiappori's initial contribution, identification required second order derivatives. In our case, to the contrary, equations (3) and (4) show that the partials of the sharing rule (hence the sharing rule itself, up to an additive constant) can be recovered as functions of the first order derivatives of the labor supplies (functions $A, B, C_{l}$ and $\left.D_{l}\right)$. This suggests that the kind of identification that may obtain is more robust in this case. ${ }^{13}$

The same remark applies to the testable predictions generated by the model, although the order of derivation must then be increased by one. The conditions above involve the first derivatives of the functions $A, B, C_{l}$ and $D_{l}$, hence the second derivatives of labor supplies, whereas third derivatives were in general involved in Chiappori's initial model.

\footnotetext{
${ }^{12}$ However, a non parametric estimation procedure requires a detailed modelling of the unobserved heterogeneity. See Blundell et al. (2000).

${ }^{13}$ Note, however, that an alternative approach relying on second derivatives can still be used (in the case, for instance, when $C_{l}=D_{l}$ for all $l$ ). This can be shown to generate identical results. Intuitively, the second order conditions in Chiappori (1992) are direct consequences of the restrictions in Proposition 2 .
} 
3. Finally, condition $(2 i)$ implies that the relative effects of distribution factors on each labor supply are equal, that is, $h_{s_{l}}^{1} / h_{s_{1}}^{1}=h_{s_{l}}^{2} / h_{s_{1}}^{2}$, for $l=2, \cdots, L$, since both members of this equation are equal to $\phi_{s_{l}} / \phi_{s_{1}}$. This conclusion is not surprising, since the model at stake, as a particular case of the general model developed above, must satisfy condition (R) of Proposition 1.

\subsection{Caring}

The set of results derived in Proposition 2 are based on the assumption that preferences are egotistic. However, as shown in Chiappori (1992), they also hold in the more general case of "caring" agents [see Becker (1991)], that is, whose preferences are represented by a utility function that depends on both his or her egotistic utility and his or her spouse's. Formally, member $i$ 's utility function can be written as:

$$
W^{i}=W^{i}\left[U^{1}\left(1-h^{1}, C^{1}, z\right), U^{2}\left(1-h^{2}, C^{2}, z\right)\right], \quad \text { for } i=1,2 .
$$

where $W^{i}$ is continuous, increasing and quasi-concave in "egotistic" utilities $U^{1}$ and $U^{2}$. These utility functions impose separability between a member's own private goods and his or her spouse's. It is clear that any decision that is Pareto efficient under caring would also be Pareto efficient, were the agents egotistic. Assume not; then it would be possible to increase the egotistic utility of a member without decreasing the utility of the other. But this would increase the caring utility of at least one member without reducing the caring utility of any member, a contradiction. In fact, the Pareto frontier of caring agents is a subset of the Pareto frontier derived by assuming that they are egotistic [Chiappori (1992)]. In section 3, we will use these results to derive the parametric restrictions imposed by the collective model to the particular labor supply system considered in our econometric approach, and to recover the corresponding sharing rule.

\subsection{Distribution factors and labor supply: alternative expla- nations}

As mentioned in the introduction, the empirical work below applies the previous results on a specific data set, using the sex ratio and an index for divorce laws as distribution factors. While the effects of these variables on the bargaining position of spouses

provide natural explanations for their correlation with labor supply behavior, these are by no means exclusive. For instance, spatial variations in the sex ratio (defined as 
the males/females ratio) could be related to labor markets considerations [GrossbardShechtman (1993)]. One interpretation is that men will be observed to work longer hours in States with a low sex ratio because of a relatively strong demand for their services. The opposite will be observed for women. Note that these predictions run counter to those of the collective model in which case the relative scarcity of men should increase their bargaining power and thus their leisure through increased transfers from their spouse. The two theories have opposite empirical predictions, which suggests that data should allow to discriminate between them.

A second explanation involves demand for labor. Assume that some States specialize in "male" sectors, i.e., sectors with a stronger relative demand for male labor supply. These States will attract relatively more men through migration. Therefore, they will have high (endogenous) sex ratios and presumably high male hours of work. Female hours of work may conceivably be well below the national average in such states. Conversely, States that concentrate in "female" sectors will have low (endogenous) sex ratios and high female hours of work. Note that this effect, in contrast with the previous, goes in the same direction as the "collective" explanation. The empirical distinction between them is thus less straightforward, but still not out of reach. First, strong labor demand should translate into high wage rates. Conditioning the hours equations on the individual wages rates should at least partly account for the tight male or female labor markets. A second way around is to focus on the relation between the sex ratio and the labor supply of singles. According to the marriage market hypothesis, the sex ratio should have no effect on their labor supply (at least if one ignores its impact on transfers to potential spouses). The labor market hypothesis, to the contrary, predicts that the sex ratio should influence the labor supply of both singles and couples. This suggests a simple and rather strong test that allows to discriminate between the two explanations.

Interestingly, a similar analysis can also be conducted with respect to the correlation between divorce laws and household labor supply. While the impact of these laws on the bargaining power of spouses is likely the most plausible explanation, alternative theories can be proposed to justify the correlation. Indeed, a host of socioeconomic or cultural factors may underlie the design of divorce laws (e.g., Ellman and Lohr 1998). Such factors may or may not be correlated with spouses' labor supply. As long as the (unobservable) socioeconomic factors which affect divorce laws and spouses' labor supply also influence singles' labor supply, we should observe a correlation between the divorce rules and singles' labor supply. No correlation should be expected if the collective model is the proper explanation. Just as previously, focusing on the relation between divorce laws and the labor supply of singles provides a simple test to assess the importance of alternatives explanations. 
Finally, it should be stressed that the collective model provides strong restrictions upon how distribution factors may affect behavior. Specifically, the conditions in Proposition 2 relate the effect of these factors to that of wages and nonlabor income. While these conditions are direct consequences of the collective setting, they have no reason to hold whenever the effect under consideration stems from labor market mechanisms. Consequently, they provide a distinct and additional means of testing the collective explanation. These tests will be carefully considered in the empirical sections.

\section{Parametric Specification of the Model}

\subsection{Functional form of labor supplies}

In order to estimate and test a collective model of labor supply, we must first specify a functional form for individual labor supply functions. Let us consider the following unrestricted system, where for convenience and to reflect the empirical analysis, two distribution factors are assumed:

$$
\begin{aligned}
h^{1}= & f_{0}+f_{1} \log w_{1}+f_{2} \log w_{2}+f_{3} y+ \\
& f_{4} \log w_{1} \log w_{2}+f_{5} s_{1}+f_{6} s_{2}+f_{7}^{\prime} z ; \\
h^{2}= & m_{0}+m_{1} \log w_{1}+m_{2} \log w_{2}+m_{3} y+ \\
& m_{4} \log w_{1} \log w_{2}+m_{5} s_{1}+m_{6} s_{2}+m_{7}^{\prime} z,
\end{aligned}
$$

where the $f_{i}$ 's and the $m_{i}$ 's, for $i=1, \cdots, 6$, are scalar, and $f_{7}^{\prime}$ and $m_{7}^{\prime}$ are $K$-vectors of parameters.

The generalized semi-log system (6) and (7) satisfies a number of desirable properties. First, in its unrestricted form, it does not impose all the (equality) conditions of the collective model. Therefore, the latter yields a set of restrictions that can be empirically tested. Second, as shown below, these restrictions do not impose unrealistic constraints on behavior. Third, assuming that the collective restrictions are satisfied, it is possible to recover a closed form for the sharing rule (up to an additive function $\kappa(z)$ ) and for the pair of individual indirect utility functions (for any given $\kappa(z)$ ). Finally, the fact that equations (6) and ( 7) are linear in parameters eases the estimation. 
Of course, this generalized semi-log system also has some limitations. While some restrictions of the unitary model consistent with this system do not impose unrealistic labor supply behavior, other restrictions do and therefore cannot be tested. ${ }^{14}$ However, this should not be a serious problem since the unitary model of household labor supply has been rejected in many studies [e.g., Lundberg (1988) and Fortin and Lacroix (1997)]. Second, labor supply curves are either everywhere upward sloping or everywhere backward bending, though the sign of $\partial h^{i} / \partial w_{i}$ can change with the level of $w_{j} \quad(j \neq i){ }^{15}$ Note, however, that the log form for the wage rates is likely to reflect more realistic behavior than the linear form that is frequently used in empirical studies. Thus it allows the effect of the wage rate on labor supply to decrease with the level of hours of work (when the labor supply is upward sloping), which is likely to be the case. ${ }^{16}$

The restrictions imposed by the collective model (see Proposition 2) to the generalized semi-log system can easily be derived. First, using the definitions of $A, B, C_{l}$ and $D_{l}$ $(l=1,2)$, one gets:

$$
\begin{aligned}
A=\frac{f_{2}+f_{4} \log w_{1}}{w_{2} f_{3}}, \quad B=\frac{m_{1}+m_{4} \log w_{2}}{w_{1} m_{3}} \\
C_{1}=\frac{f_{5}}{f_{3}}, \quad C_{2}=\frac{f_{6}}{f_{3}}, \quad D_{1}=\frac{m_{5}}{m_{3}}, \quad D_{2}=\frac{m_{6}}{m_{3}} .
\end{aligned}
$$

The condition $C_{1} \neq D_{1}$ is satisfied unless

$$
\frac{m_{3}}{f_{3}}=\frac{m_{5}}{f_{5}} .
$$

It should be stressed that under the collective model, this equation is unlikely to be satisfied. For one thing, $\frac{m_{3}}{f_{3}}$ represents the ratio of income effects on labor supplies; the

\footnotetext{
${ }^{14}$ More specifically, the unitary model imposes that labor supplies are independent from any distribution factor and that the Slutsky matrix of compensated wage effects is symmetric and semidefinite positive. The former constraint requires that $f_{5}=f_{6}=m_{5}=m_{6}=0$. These restrictions can be tested. However, the symmetry of the Slutsky matrix requires in addition either that (i) $f_{2}=f_{3}=f_{4}=m_{1}=m_{3}=m_{4}=0$, which implies that each labor supply depends only on own wage rate and on preference factors, or that (ii) $f_{0}=m_{0}, f_{3}=m_{3}, f_{7}=m_{7}$ and $f_{1}=f_{2}=f_{4}=m_{1}=m_{2}=m_{4}=0$, which implies that labor supplies are the same and depend only on nonlabor income and on preference factors. It is clear that these two cases impose severe constraints on behavior.

${ }^{15}$ Using our data set, we tested a more flexible functional form by introducing a second order polynomial in $\log w_{1}, \log w_{2}$ and $y$. No coefficients associated with the second order variables were found significant (except for the one associated with the cross term in $\log w_{1}$ and $\log w_{2}$ ).

${ }^{16} \mathrm{It}$ is also worth mentioning that our specification can easily allow for interactions between distribution and preferences factors.
} 
latter is positive as long as leisure is a normal good for both members and that an increase in $y$ is shared between them. On the other hand, $\frac{m_{5}}{f_{5}}$ represents the corresponding ratio of the effects of the distribution factor. Since, by definition, any distribution factor affects the husband's and the wife's share of nonlabor income in opposite directions, the ratio must be negative.

Assuming $C_{1} \neq D_{1}$, the necessary and sufficient conditions take the following form:

$$
\frac{m_{4}}{f_{4}}=\frac{m_{5}}{f_{5}}=\frac{m_{6}}{f_{6}}
$$

Equations (8) summarizes the equality restrictions on labor supply arising from the collective framework. In other words, given our functional form, they are equivalent to conditions (2a)-(2f) and (2i). They actually take a very simple form since only equations (2f) and (2i) impose restrictions. ${ }^{17}$ This indicates that the functional form under consideration "fits well" the collective model. In practice, equations (8) impose testable cross-equation restrictions in our labor supply system. They require the ratio of the marginal effects of the cross term in $\log w_{1}$ and $\log w_{2}$ to be equal to the corresponding ratio of the marginal effects of each distribution factor on labor supplies. These restrictions stem from the fact that the cross term and the distribution factors enter labor supply functions only through the same function $\phi$. Notice that the last equality in (8) holds also when externalities are allowed since it corresponds to $(R)$ in Proposition 1.

\subsection{Sharing rule}

If the restrictions (8) are satisfied, the partials of $\phi$ are given by :

$$
\begin{aligned}
\phi_{y} & =\frac{f_{3} m_{4}}{\Delta}, \\
\phi_{s_{1}} & =\frac{m_{4}}{\Delta} f_{5}, \quad \phi_{s_{2}}=\frac{m_{4}}{\Delta} f_{6}, \\
\phi_{w_{1}} & =\frac{f_{4}}{\Delta} \frac{m_{1}+m_{4} \log w_{2}}{w_{1}} \\
\phi_{w_{2}} & =\frac{m_{4}}{\Delta} \frac{f_{2}+f_{4} \log w_{1}}{w_{2}}
\end{aligned}
$$

where $\Delta=f_{3} m_{4}-f_{4} m_{3}$.

\footnotetext{
${ }^{17}$ Equations (2a)-(2e) are always satisfied since all partial derivatives in these equations are zero.
} 
Solving this four differential equations system, one obtains the sharing rule equation:

$$
\begin{aligned}
\phi= & \frac{1}{\Delta}\left(m_{1} f_{4} \log w_{1}+f_{2} m_{4} \log w_{2}+f_{4} m_{4} \log w_{1} \log w_{2}+\right. \\
& \left.f_{3} m_{4} y+m_{4} f_{5} s_{1}+m_{4} f_{6} s_{2}\right)+\kappa(z),
\end{aligned}
$$

In equation (10), the function $\kappa(z)$ is not identifiable, since the variable $z$ affects both the sharing rule and the preferences. This reflects the fact that, for any given $z$, the sharing rule can be recovered up to an additive constant for each individual.

\subsection{Individual labor supplies}

It is also possible to recover the individual labor supply functions associated with this setting. Since they must have a functional form consistent with equations (1) and (2), it is clear, using equations (6), (7) and (10), that they take the following semi-log form:

$$
\begin{aligned}
& h^{1}=\alpha_{1} \log w_{1}+\alpha_{2} \phi+\alpha_{3}(z), \\
& h^{2}=\beta_{1} \log w_{2}+\beta_{2}(y-\phi)+\beta_{3}(z) .
\end{aligned}
$$

Using the expressions for the partials of the restricted system (1) and (2) with respect to $\left(w_{1}, w_{2}, y\right)$ and the partials of $\phi$ given by (9), one easily recovers the following parameters: $\alpha_{1}=\left(f_{1} m_{4}-f_{4} m_{1}\right) / m_{4}, \alpha_{2}=\Delta / m_{4}, \beta_{1}=\left(f_{4} m_{2}-f_{2} m_{4}\right) / f_{4}$ and $\beta_{2}=-\Delta / f_{4}$. The functions $\alpha_{3}(z)$ and $\beta_{3}(z)$ are not identifiable since they depend on $k(z)$ in equation (10). ${ }^{18}$

Slutsky conditions on compensated individual labor supplies [see (2g) and (2h) in Proposition 2], are given by:

$$
\alpha_{1} / w_{1}-\alpha_{2} h_{1} \geq 0, \quad \beta_{1} / w_{2}-\beta_{2} h_{2} \geq 0 .
$$

\footnotetext{
${ }^{18}$ Identification of these functions would require additional identifying restrictions. For instance, it obtains whenever a variable in $z$ affects preferences but not the sharing rule.
} 
These conditions are verified for each observation in the empirical analysis. Global conditions for these inequalities are $\alpha_{1} \geq 0, \alpha_{2} \leq 0, \beta_{1} \geq 0$ and $\beta_{2} \leq 0$.

\subsection{Indirect utility functions}

It can be shown [Stern (1986)] that the indirect utility functions consistent with the labor supply functions (11) and (12) must have the following form:

$$
\begin{aligned}
v^{1}\left(w_{1}, \phi_{1}, z\right)= & \left.\left(\exp \left(\alpha_{2} w_{1}\right)\right) / \alpha_{2}\right)\left(\alpha_{2} \phi_{1}+\alpha_{3}(z)+\right. \\
& \left.\alpha_{1} \log w_{1}\right)-\left(\alpha_{1} / \alpha_{2}\right) \int_{-\infty}^{\alpha_{2} w_{1}} \exp (t) / t d t, \\
v^{2}\left(w_{2}, \phi_{2}, z\right)= & \left(\exp \left(\beta_{2} w_{2}\right) / \beta_{2}\right)\left(\beta_{2} \phi_{2}+\beta_{3}(z)+\right. \\
& \left.\beta_{1} \log w_{2}\right)-\left(\beta_{1} / \beta_{2}\right) \int_{-\infty}^{\beta_{2} w_{2}} \exp (t) / t d t .
\end{aligned}
$$

It is easy to show that Roy's identity applied to each of these indirect utility functions yields the individual labor supply system (11) and (12). These functions (or the corresponding expenditure functions) can be used to perform intra-household welfare analysis of changes in exogenous variables.

\section{Data and empirical results}

\subsection{Data}

The data we use in this study are taken from the University of Michigan Panel Study of Income Dynamics (PSID) for the year 1988 (interview year 1989). Our sample consists of 1618 households where both spouses have positive hours of work and are between 30 and 60 years of age. ${ }^{19}$ This latter restriction was used in order to eliminate as much as possible full-time students and retired individuals, and to reduce cohort effects.

\footnotetext{
${ }^{19}$ Conditioning the sample on working spouses may induce a selectivity bias especially in the case of females. We ignore this bias in the analysis. The basic reason is that such a correction requires an
} 
Removing couples in which spouses are aged less than 30 increases the proportion of "stable" households, for which the hypothesis of efficiency in the intra-household decision process is more likely to be satisfied.

The dependent variables, male and female annual hours of work, are defined as total hours of work on all jobs during 1988. The measure of the wage rate is the average hourly earnings, defined by dividing total labor income over annual hours of work. Nonlabor income includes, among other things, imputed income from all household net assets ${ }^{20}$ and is net of total household savings. ${ }^{21}$ This variable is treated as an endogenous variable in the empirical section. It should be stressed that the PSID provides information on net assets at the beginning of periods 1984 and 1989. Therefore our measure of savings is the annual average change in total net household assets over this period (expressed in 1988 dollars). In order to reduce measurement errors on this variable, we further restricted our sample to households with stable couples over the 1984-1989 period.

Table 1 presents descriptive statistics for our sample. The upper and middle panels report statistics on individual households whereas the bottom panel focuses on various aspects of the marriage market. According to the data in the top panel, men work on average more yearly hours than women and earn a somewhat higher hourly wage rate. Men are also nearly three years older than their spouse on average, both they both have similar schooling levels. The distribution by race is identical among men and women. A close look at the data reveals that there are very few interracial marriages in our sample.

The middle panel reports the average number of pre-schoolers and school age children per household as well as household nonlabor income. These variables are all treated as

extension of the collective model to corner solutions, a task that is beyond the scope of this paper. The reader is referred to Blundell et al. (2000) and Donni (1999) for an investigation of the related (but different) problem of discrete labor supply decisions. There is some evidence that the selectivity bias is not likely to be a problem though. For instance, using PSID data, and based on a standard recursive labor supply model, Mroz (1987) could not reject the hypothesis of no selectivity bias in women's labor supply equation.

${ }^{20}$ We use a nominal interest rate of $12 \%$.We also experimented with nominal interest rates of $8 \%$ and $10 \%$ but this did not significantly affect the results.

${ }^{21}$ Removing household savings from the measure of nonlabor income is consistent with an intertemporally separable life-cycle model involving a two stage budgeting process. In the first stage, the couple optimally allocates life-cycle wealth over each period in order to determine the vector of periodspecific levels of nonlabor income net of savings. At each period, nonlabor income net of savings plus total household wage income is equal to the level of household consumption expenditures (this represents period-specific household budget constraints). The second stage corresponds to period-specific Pareto efficient allocations of goods and labor supplies [see Blundell and Walker (1986) for a discussion of a life-cycle two stage budgeting process in the case of a one-individual household]. 
endogenous in the empirical work. Although there is mixed evidence concerning the endogeneity of number of children in women's labor supply [e.g., Mroz (1987)], we deem preferable to instrument these variables. The average nonlabor income per household is approximately $\$ 8000$. Its large variance is essentially due to the fact that younger households tend to have negative assets (mortgage) whereas older households have (on average) positive assets.

Our sex ratio index is computed at the state level using data from the Census of Population and Housing of 1990. It corresponds to the number of males that are of the same age and same race as the husband of each household over the corresponding number of males and females. We experimented with various definitions of the sex-ratio: means of sex-ratios using the number of females who are two years younger than the husband or based on individuals who are at most 2 or 5 years younger than the husband of each household. The results were very robust to the definition used. ${ }^{22}$ Our sex ratio index is computed under the assumption that the relevant marriage market is limited to one's own race. As shown in the Table 1, the mean sex ratio is slightly higher for Whites than it is for Blacks, but the latter has a larger variance that is observable both state-wise and age-wise.

The model was also estimated using sex-ratios computed at the county level. The county of residence reported in the PSID was matched to county level data on male and female populations from the 5\% Public Use Microdata Sample of the 1990 census. Unfortunately, many cases turned out to have too few observations to compute meaningful sex ratios. Sex ratios for blacks were particularly prone to measurement errors. We thus used state sex ratios as instruments for county sex ratios. The results were very similar to those reported here. ${ }^{23}$

\footnotetext{
${ }^{22} \mathrm{~A}$ very natural question, however, is whether the appropriate measure of the sex ratio is in terms of the marriage market or, alternatively, in terms of the remarriage market. The issue, here, boils down to a commitment problem. Assuming that couples are able to make up-front binding commitment at the date of marriage, only the balance of powers (hence the sex ratio) at that date should matter. If, conversely, such commitments cannot be perfectly enforced, then one should rather consider the current value of the sex ratio. From a theoretical perspective, one can probably prefer the second interpretation, since members cannot commit not to divorce. Should the prospects on the remarriage market brutally evolve, a renegotiation of the initial contract is difficult to prevent, especially when, in the new context, remaining married would violate one member's individual rationality constraint. An informal support to this view is provided by Thomas et al.'s (1997) finding that wealth at marriage does not seem to influence the intra-household balance of power in those Indonesian regions where wealth is traditionally pooled within the household.

${ }^{23}$ For the sake of brevity these results are omitted from this paper, although they are available upon request.
} 
Four features of the divorce laws are considered in the empirical analysis: mutual consent vs unilateral, property division, enforcement of support orders, and spousal interest in professional degrees and licenses. ${ }^{24}$ As of 1989, most states (42) had adopted unilateral-divorce laws. Among these, as many as 24 allowed unilateral divorce only after a lengthy separation that lasted between 6 months and 5 years. We follow Peters (1986) and Gray (1998) and define them as mutual-consent states. Property division refers to state marital-property systems which can be either of community-property or commonlaw. ${ }^{25}$ Courts do not have the same discretion to protect vulnerable parties (usually women) under common-law. Therefore married women's bargaining power is likely to be stronger in community-property jurisdictions. Furthermore, insofar as household assets are disproportionately in the husband's name, mutual-consent divorce law also advantages women in common-law states, ${ }^{26}$ which represent $96 \%$ of our sample, though it disadvantages women in community-property states. ${ }^{27}$ Enforcement of support orders relates to the ability of the state to have payment made directly to court officers. Finally, spousal interest in professional degrees refers to states which treat the value of degrees and licenses as divisible property upon divorce. The two latter features are likely to favor women.

The bottom panel of Table 1 reports mean values for all four features. ${ }^{28}$ These are dummy variables that equal 1 in cases that are deemed to increase women's bargaining power. As shown in the table, few households in our sample fall under the community-property system and most are in unilateral states. Likewise, the majority of our households live in states that provide direct payments of support orders to the courts, and roughly half live in states that treat degrees and licenses as divisible assets upon marital dissolution. Following a simple econometric test discussed below, all four

\footnotetext{
${ }^{24}$ Other features of divorce laws have been considered in preliminary work. Unfortunately, none turned out to be statistically significant. A very detailed discussion of state divorce laws relevant to our sample period can be found in Freed and Walker (1991).

${ }^{25}$ Arizona, Mississippi and Nevada are community-property states that provide for "equitable" rather than "equal" distribution of property upon dissolution. They are thus treated as common-law states.

${ }^{26}$ Notice however that, at one extreme tail of the distribution, there is some evidence showing that switch from mutual-consent to unilateral-divorce laws led to a reduction in female suicide, domestic violence and in the number of females murdered by their partners (Stevenson and Wolfers 2000). Presumably, these effects could partly be explained by a greater accessibility to divorce.

${ }^{27}$ This suggests, following Gray (1998), to introduce interactive terms between the mutual-consent and the community-property dummy variables in the equations of the model. However these terms were never significant in any equation, presumably because of the very small proportion (4\%) of communityproperty states in our sample.

${ }^{28}$ Note that the means represent state averages weighted by the distribution of our sample across the various states.
} 
features of state divorce laws are aggregated into a single indicator that we refer to as "Divorce Laws Index". This variable is a rough proxy of the extent to which state divorce laws are "favorable" to women in a bargaining context. In our sample, it ranges between 1 and 4 with an average of 2.48 . Its large standard error $(=0.88)$ indicates that some states have few provisions that favor women, whereas others have many.

\subsection{Results}

The parametric form that we estimate was introduced in equations (6) and (7). ${ }^{29}$ Preference factors include the number of pre-school age children, the number of school age children, education, age, dummy regional variables and a race dummy (=1 if white). This specification is relatively standard in the labor supply literature [e.g., Mroz (1987)]. It must be stressed that the race dummy controls for the potential correlation that may exist between the sex ratio and labor supply that could arise due to a race effect. ${ }^{30}$

Before discussing the results, the issue of endogenous covariates must be addressed. Indeed, unobserved individual characteristics may be positively correlated with wages and/or nonlabor income and hours of work, thus creating spurious correlation between right hand-side variables and the error terms of the hours equations. We thus follow Mroz (1987) and use a second order polynomial in age and education to instrument the wages, the nonlabor income and the number of pre-schoolers and school age children. ${ }^{31}$ Other instruments include father education, religion and city size ( 3 dummies). In the unrestricted version, there are 28 parameters to estimate and over 68 instruments (see Tables 2 and 3 for the complete list of instruments).

The various versions of the model are estimated using a full information GMM method. One advantage of this approach is that it also takes into account heteroskedasticity of unknown form in the errors, which can not be done using a full information maximum likelihood method [see Davidson and MacKinnon (1993), ch.18]. Therefore, in the presence of heteroskedasticity of unknown form our estimator should be asymptotically more efficient than 3SLS or FIML. ${ }^{32}$

\footnotetext{
${ }^{29}$ We also estimated the model by distinguishing between husband's and wife's nonlabor income to provide one additional distribution factor. Unfortunately, the parameter estimates were never statistically significant when doing so.

${ }^{30}$ We also estimate the model separately for Blacks and Whites. The results are quite similar but less precise than those reported in this sub-section.

${ }^{31}$ The estimated coefficients of wages and nonlabor income are relatively insensitive to the instrumentation of the children variables.

${ }^{32}$ In the unrestricted form of our model, which is linear in parameters, our estimator is identical to the
} 
Table 2 provides estimation results. In the first two columns, we report the parameter estimates of the unrestricted model in which the distribution factor reflecting the state divorce laws is first broken down into four separate dummy variables. Most parameter estimates are statistically significant at conventional levels. In particular, those associated with wage rates, nonlabor income, and sex ratio are statistically significant at the $5 \%$ or $10 \%$ level. A Hansen's test does not reject the validity of the instruments and the over-identifying restrictions. The test statistic of 22.9 is to be compared with the critical value of the $\chi_{0.05}^{2}(40)=55.7$.

The parameter estimates of the unrestricted model provide interesting results that are worth mentioning. For instance, according to our results, a one percentage unit increase in the sex ratio reduces wives' annual labor supply by 17,9 hours while it increases husbands' labor supply by 45 hours. These results thus reject an important restriction of the unitary model according to which no distribution factor influences behavior. It also rejects the simple version of the "separate spheres" model (Lundberg and Pollak 1993) which assumes that the threat point is not divorce but an uncooperative marriage. ${ }^{33}$ Further evidence on this matter is provided by the parameter estimates associated with the state divorce law variables. Indeed, many of them are statistically significant and of opposite sign in women's and men's equations. For instance, women living in community-property states and those living in mutual consent states tend to work less than otherwise. On the other hand, men living either in states which have stringer enforcement laws or that treat licenses and professional degrees as divisible assets tend to work more than others. These results are also incompatible with both the unitary model and the simple version of the "separate spheres" model.

The parameter estimates of the divorce law dummy variables in each regression are relatively similar in magnitude. A joint Wald test of equality of coefficients in wives' labor supply and of equality of coefficients in husbands' labor supply yields a statistic of 0.88 which is much smaller than critical value of $\chi_{0.05}^{2}(6)=11.07$. We thus add up the dummy variables into a single indicator and report the estimation results of the unrestricted model that uses this "Divorce Laws Index" in the second column of the

Davidson-MacKinnon's H3SLS estimator. The acronym refers to a modified version of the conventional 3SLS estimator that attains greater efficiency in the presence of heteroskedasticity of unknown form. However our estimator does not correspond to the H3SLS estimator in the restricted version of the model since the restrictions on the parameters are nonlinear.

${ }^{33}$ Theoretically, one could also test restrictions of this model (or alternative bargaining models) that stem from the particular formulation of the Nash bargaining program. However, these restrictions are likely to be very difficult to derive formally [see McElroy (1990) and Chiappori (1992) for a recent discussion]. 
table. The results of this model are very similar to those of the model with divorce laws dummies. According to our estimates, a one point unit increase in the index, which reflects the adoption of a divorce law deemed favorable to women, reduces wives' labor supply by approximately 46 hours while it increases husbands' labor supply by 81 hours over a year.

As discussed above, it can be argued that tests of the unitary or "separate spheres" models may be biased since the sex ratio and divorce laws are likely to be correlated with unobserved variables related to the labor markets. We suggested in Section 2 a convenient way to discriminate between the marriage market and the labor market hypotheses, namely to analyze the impact of the distribution factors on the labor supply of singles: the latter should be zero according to the marriage market hypothesis, whereas, in the labor market story, the sex ratio should influence the labor supply of both singles and couples in a similar way. Table 3 reports OLS and GMM regression results of male and female singles' hours of work. ${ }^{34}$. In both GMM estimations, Hansen tests do not reject the validity of the instruments and the over-identifying restrictions. We find that the sex ratio is statistically significant only in the GMM regression on the sample of women, but its parameter estimate is of opposite sign to that of wives. Furthermore, the Divorce Laws Index is not statistically significant in either the male or female regressions. We conclude that although the sex ratio and the divorce laws may partly reflect conditions on the labor market, it probably is not the whole story.

The columns associated with the general collective model in Table 2 provide results based on the assumption that the ratios of the effects of the sex ratio to the Divorce Laws Index on labor supplies are equal. This corresponds to the equality $\frac{m_{5}}{f_{5}}=\frac{m_{6}}{f_{6}}$ in conditions (8). ${ }^{35}$ The coefficients are very similar in the unrestricted and the restricted versions. Moreover, a Newey-West's test does not reject the validity of this restriction. The test statistic is equal to the difference in function values of the restricted and unrestricted versions $(=0.024)$ and is much smaller than the relevant critical value of $\chi_{0.05}^{2}(1)=3.84$. Therefore, our results do not reject the general version of the collective model which allows for externalities of any kind.

The next columns provide results of the collective model with caring. The constraints imposed by this more restrictive model boil down to $\frac{m_{4}}{f_{4}}=\frac{m_{5}}{f_{5}}=\frac{m_{6}}{f_{6}}$, as given by (8),

\footnotetext{
${ }^{34}$ We did not use the same age group as the one used for couples (30-60) since doing this severely reduced the sample size and made most coefficients non significant.

${ }^{35}$ One must reckon that the test performed is approximative since our Divorce Laws Index is a discrete variable. This implies that, strictly speaking, the weighting factor $\mu\left(w_{1}, w_{2}, y, z, s\right)$ is not differentiable in this index, which violates an assumption of our general model.
} 
where $\frac{m_{4}}{f 4}$ is the ratio of the effects of the cross-wage variable (in log) on labor supplies. Again, one cannot reject this joint hypothesis since the Newey-West test statistic is equal to $2.58<\chi_{0.05}^{2}(2)=5.99$. Should the distribution factors reflect only labor market mechanisms, there would be no reason to expect that these specific restrictions be satisfied. Interestingly, using Wald tests (test statistics of 4.5 and 4.8, respectively), one rejects the hypothesis that $C_{1}=D_{1}$ and $C_{2}=D_{2}$, where subscript 1 holds for the sex ratio and subscript 2 for the Divorce Laws Index. This provides support for the theoretical approach we used to derive the restrictions of the model. Also, Slutsky conditions on the labor supply of women are globally satisfied while they are locally satisfied for all men in the sample. All in all, these tests do not reject the collective model with caring. The last column of Table 2 reports the implicit parameters of women's sharing rule as derived from the restricted parameters of the model with caring and using equation (10). All parameter estimates of the sharing rule (except that of $\log w_{h}$ ) are statistically significant at conventional levels.

In order to gain insight into the interpretation of the parameters of the sharing rule, Table 4 reports the partial derivatives of the sharing along with their standard errors. The first column of the table replicates last column of Table 2. The second column reports the partial derivatives themselves. They represent the impact of a marginal change in one variable on the nonlabor income accruing to the wife after sharing. According to our parameter estimates, a one dollar increase in the wife's wage rate, $\omega_{f}$, (which is equivalent to an annual increase of $\$ 1,740$ (1988) in her labor income, at the mean of hours worked by women) translates into more income being transferred to her husband. At sample mean, the transfer amounts to $\$ 1,634$, although this effect is not precisely estimated. Also, a one dollar increase in the husband's wage rate, $\omega_{h}$, (equivalent to an annual increase of $\$ 2,240$ in his labor income) translates into more income being transferred to his wife. Indeed, the table shows that, at the mean of the sample, $\$ 600$ will be transferred to his wife, but again this effect is imprecisely estimated. These results suggest that wives in our sample behave in more altruistic manner toward their husband than the other way around, though the effects are not measured with much precision. The next line indicates that a one dollar increase in household nonlabor income will increase the wife's nonlabor income by 70 cents.

The next couple of lines report the impact of the distribution factors on the intrahousehold allocation of nonlabor income. As indicated, a one percentage point increase in the sex ratio will induce husbands to transfer an additional $\$ 2,163$ of income to their spouse. Likewise, a one point increase in the Divorce Laws Index similarly induces husbands to transfer and additional $\$ 4,310$ to their wives. Both estimates are statistically significant at conventional levels and provide strong support to the fact that external 
factors may have sizeable impacts on the intra-household decision process. ${ }^{36}$

The other columns of Table 4 report various labor supply elasticities. In general these elasticities are comparable to those found in the empirical labor supply literature. At the sample mean, women's wage elasticities are positive and statistically significant in the unrestricted model and the two versions of the collective model. They are also very close varying between 0.227 and 0.235 . Men's wage elasticities are negative but very small (varying between -0.073 and -0.103 ) and not statistically significant. Crosswage elasticities are all negative and statistically significant only in the case of husbands' labor supply. Moreover, both men's and women's labor supply elasticities with respect to nonlabor income are negative. Moreover, they are significant at the $5 \%$ or the $10 \%$ level.

The last two columns of the table report the own-wage elasticities of individual labor supplies, conditional on after sharing nonlabor income ( $\phi$ and $y-\phi$, respectively). These elasticities are derived from equations (11) and (12) and rely on individual preferences alone since they ignore any effect wage rates may have on the intra-household decision process. Both women's and men's elasticities are significant but smaller than those reported in the two previous columns. This simply reflects the fact that, in the latter cases, a marginal increase in either spouse's wage rate reduces their share of the nonlabor income, which in turn increases their labor supply through an income effect.

\section{Conclusion}

The purpose of this paper is twofold. We first extend Chiappori's (1992) collective model of household labor supply to account for so-called distribution factors. The main thrust behind this model is the assumption that the household decision-process, whatever its true nature, leads to observed outcomes that are pareto-efficient. It also assumes that preferences are egotistic or "caring" in the Beckerian (1991) sense. Distribution

\footnotetext{
${ }^{36}$ The model was also estimated using a sample that excluded couples with preschoolers. Arguably, young children constitute the most important source of non-separability in spouses' preferences [Lundberg (1988)]. Consequently, including such families in the sample increases the likelihood of rejecting the collective model with caring. The results based on the restricted sample are very similar to those obtained using the full sample. The only noticeable difference relates to the impact of the distribution factors. Both an increase in the sex ratio and in the Divorce Laws Index generate much larger transfers from the husband to his wife when there are no preschoolers in the household. Presumably, spouses are more responsive to changes in the marriage market in the absence of young children. These results are not reported in the paper for the sake of brevity but are available on request.
} 
factors are variables that are thought to affect the internal decision process but to have no incidence on individual preferences or the joint consumption set. By introducing distribution factors into the model, we show that the identification of the structural parameters is greatly simplified. Furthermore, the introduction of distribution factors generates new testable restrictions. Also, when at least two distribution factors are assumed, the efficiency assumption can be tested even when very general preferences with externalities of any kind (including public goods) are allowed.

The second goal of the paper is to provide further empirical evidence on the efficiency assumption as well as on the relevance of distribution factors to the internal decision process. The two factors we consider are state-level sex ratios and a compendium of state divorce laws. The empirical analysis is based on household labor supply drawn from the 1989 wave of the PSID. The efficiency hypothesis, both in a model with caring preferences and in one with very general preferences, can not be statistically rejected. Indeed, the non-linear parametric constraints that derive from both models are consistent with the data. Our results thus reject one important prediction of the unitary model, namely that distribution factors are irrelevant to intra-household decisions. They are also at odds with Nash bargaining models that assume that the fall-back option is internal to the household. Quite to the contrary, we provide some support for Becker's (1991) claim that the state of the marriage market is an important determinant of the intra-household decision process.

Under the assumptions of efficiency and caring preferences, it can be shown that the internal decision process may be viewed as a two-step process: Nonlabor income is first allocated among spouses according to a so-called sharing rule that depends on distribution factors and other variables. Next, spouses choose their labor supply subject to their individual budget constraint. Given efficiency was not rejected, the parameters of the sharing rule associated with our model can be recovered (up to a constant) and analyzed. It turns out that most parameters of the sharing rule are significantly different from zero. In particular, we find that a one percentage point increase in the proportion of males in a population defined by age, race and jurisdiction induces husbands in this population to increase their transfer to their wife by $\$ 2,163$ on average. Likewise, passage of a divorce law that is favorable to women will induce husbands to transfer, on average, an additional $\$ 4,310$ to their wife. The latter result illustrates the usefulness of the collective approach in analyzing the consequences of public policies, and in particular divorce legislation, on the allocation of income and welfare within marriage.

We reckon our empirical analysis is subject to some limitations though. Indeed, our estimates are conditioned on a sample of individual that have chosen to live with a 
spouse and could suffer from selectivity biases as a result. In regions where the sex ratio is relatively small, more "low-quality" men are likely to marry given the scarcity of men in the marriage market. A positive correlation between quality in the marriage market and in the labor market will yield a spurious correlation between the sex ratio and male hours of work. More research on collective models that endogenize both marital choices and labor supply is clearly needed.

Finally, our approach assumes that the sex ratio is exogenous. It can be argued that this variable adjusts across regions to equilibrate the marriage markets [Becker (1991)]. While we present some evidence that suggests otherwise, it would be important to pay more attention to the factors that explain variations of the sex ratio across regions. 


\section{APPENDIX : Proof of Proposition 3}

\section{A One distribution factor}

Start from :

$$
\begin{gathered}
h^{1}=H^{1}\left(w_{1}, \phi\left(w_{1}, w_{2}, y, s, z\right), z\right), \\
h^{2}=H^{2}\left(w_{2}, y-\phi\left(w_{1}, w_{2}, y, s, z\right), z\right) .
\end{gathered}
$$

Then :

$$
\begin{gathered}
A=\frac{h_{w_{2}}^{1}}{h_{y}^{1}}=\frac{\phi_{w_{2}}}{\phi_{y}}, \\
B=\frac{h_{w_{1}}^{2}}{h_{y}^{2}}=\frac{-\phi_{w_{1}}}{1-\phi_{y}}, \\
C=\frac{h_{s}^{1}}{h_{y}^{1}}=\frac{\phi_{s}}{\phi_{y}},
\end{gathered}
$$

and

$$
D=\frac{h_{s}^{2}}{h_{y}^{2}}=\frac{-\phi_{s}}{1-\phi_{y}} .
$$

Assume that $C \neq D$. Then the last two equations give :

$$
\begin{aligned}
\phi_{y} & =\frac{D}{D-C}, \\
\phi_{s} & =\frac{C D}{D-C} .
\end{aligned}
$$

Then the first two lead to :

$$
\begin{aligned}
\phi_{w_{1}} & =\frac{B C}{D-C}, \\
\phi_{w_{2}} & =\frac{A D}{D-C} .
\end{aligned}
$$

These partials are compatible if and only if they satisfy the usual cross derivative restrictions. Hence, the following conditions are necessary and sufficient : 


$$
\begin{aligned}
\frac{\partial}{\partial s}\left(\frac{D}{D-C}\right) & =\frac{\partial}{\partial y}\left(\frac{C D}{D-C}\right) \\
\frac{\partial}{\partial w_{1}}\left(\frac{D}{D-C}\right) & =\frac{\partial}{\partial y}\left(\frac{B C}{D-C}\right) \\
\frac{\partial}{\partial w_{2}}\left(\frac{D}{D-C}\right) & =\frac{\partial}{\partial y}\left(\frac{A D}{D-C}\right) \\
\frac{\partial}{\partial w_{1}}\left(\frac{C D}{D-C}\right) & =\frac{\partial}{\partial s}\left(\frac{B C}{D-C}\right) \\
\frac{\partial}{\partial w_{2}}\left(\frac{C D}{D-C}\right) & =\frac{\partial}{\partial s}\left(\frac{A D}{D-C}\right) \\
\frac{\partial}{\partial w_{2}}\left(\frac{B C}{D-C}\right) & =\frac{\partial}{\partial w_{1}}\left(\frac{A D}{D-C}\right) .
\end{aligned}
$$

If these equations are fulfilled, then $\phi$ is defined up to an additive function $\kappa(z)$ depending only on the preference factors $z$. The inequalities $(2 g)$ and $(2 h)$ of Proposition 2 follow from standard integrability arguments. Finally, the knowledge of Marshallian labor supplies allows to recover preferences for any given value of $\kappa(z)$.

\section{B Several distribution factors}

If there are several distribution factors, then they can enter labor supply functions only through the same function $\phi$. This implies that :

$$
\frac{h_{s_{l}}^{1}}{h_{s_{1}}^{1}}=\frac{\phi_{s_{l}}}{\phi_{s_{1}}}=\frac{h_{s_{l}}^{2}}{h_{s_{1}}^{2}},
$$

for all $l$. Moreover, equations 4 that determine the $\phi_{s_{l}}$ 's are obtained in the same way as the equation for $\phi_{s}$ in the case of one distribution factor. Notice finally that condition (2i) combined with the assumption that $C_{1} \neq D_{1}$ imply that $C_{l} \neq D_{l}$, for $l=2, \cdots, L$, in equations (4). 


\section{References}

[1] Angrist, J. (2000), "Consequences of Imbalanced Sex Ratios: Evidence from America's Second Generation", mimeo, Harvard University.

[2] Becker, G. (1991), A Treatise on the Family, Cambridge, Mass.: Harvard University Press.

[3] Behrman, J.R., R.A. Pollak and P.Taubman (1995), From Parent to Child: Inequality and Immobility in the United States, Chicago: University of Chicago Press.

[4] Bertrand, M. S. Mullainathan and D. Miller (2000), "Public Policy and Extended Families: Evidence from South Africa", Mimeo, MIT.

[5] Blundell, R., P.A. Chiappori, T. Magnac and C. Meghir (2000), "Discrete Choice and Collective Labor Supply", Mimeo, UCL.

[6] Blundell, R. and I. Walker (1986), "A Life-Cycle Consistent Empirical Model of Family Labour Supply Using Cross-Section data", Review of Economic Studies, $175,539-558$.

[7] Bourguignon, F., M. Browning and P.-A. Chiappori (1995), "The Collective Approach to Household Behaviour", Working Paper 95-04, Paris: DELTA.

[8] Bourguignon, F., M. Browning, P.-A. Chiappori and V. Lechene (1993), "IntraHousehold Allocation of Consumption: a Model and some Evidence from French Data", Annales d'Économie et de Statistique , 29, 137-156.

[9] Browning, M., F. Bourguignon, P.-A. Chiappori and V. Lechene (1994), "Incomes and Outcomes: A Structural Model of Intra-Household Allocation", Journal of Political Economy, 102, 1067-1096.

[10] Browning M. and P.-A. Chiappori (1998), “ Efficient Intra-Household Allocations: a General Characterization and Empirical Tests", Econometrica, 66, 1241-1278.

[11] Chiappori, P.-A. (1988), "Rational Household Labor Supply", Econometrica, 56, $63-89$.

[12] Chiappori, P.-A. (1992), "Collective Labor Supply and Welfare", Journal of Political Economy, 100, 437-467. 
[13] Chiappori, P.-A. and Ekeland (2001), "Household Demand: a Complete Characterization", Mimeo, University of Chicago.

[14] Davidson, R. and J.G. Mackinnon (1993), Estimation and Inference in Econometrics, Oxford: Oxford University Press.

[15] Donni, O. (1999), "Collective Female Labor Supply", DELTA, mimeo.

[16] Duflo (2000), "Grandmothers and Granddaughters: Old Age Pension and Intrahousehold Allocation in South Africa", mimeo, MIT.

[17] Ellman, I.M. and S.L. Lohr (1998), "Dissolving the Relationship between Divorce Laws and Divorce Rates", International Review of Law and Economics, 18, 341-359.

[18] Fortin, B. and G. Lacroix (1997), "A Test of the Unitary and Collective Models of Household Labour Supply", Economic Journal, 107, 933-955.

[19] Freed, D.J. and T.N. Walker (1991), "Family Law in the Fifty States: An Overview", Family Law Quaterly, 24, 309-405.

[20] Friedberg, L. (1998), Did Unilateral Divorce Raises Divorce Rates? Evidence from Panel Data", American Economic Review, 88, 608-627.

[21] Galasso, E. (1999): "Intrahousehold Allocation and Child Labor in Indonesia", Mimeo, BC.

[22] Gray, J.S. (1998), "Divorce-Law Changes, Household Bargaining, and Married Women's Labor Supply", American Economic Review, 88, 628-642.

[23] Grossbard-Shechtman, A.S. (1993), On the Economics of Marriage-A Theory of Marriage, Labor and Divorce, Boulder: Wesrview Press.

[24] Grossbard-Shechtman, A.S. and M. Neideffer (1997), "Women's Hours of Work and Marriage Market Imbalances", in I. Persson and C. Jonung (eds.), Economics of the Family and Family Policies, Routledge, New York.

[25] Haddad, L., and R. Kanbur (1992), "Intra-Household Inequality and the Theory of Targetting", European Economic Review, 36, 372-78.

[26] Lundberg, S. (1988), "Labor Supply of Husbands and Wives: A Simultaneous Equations Approach", The Review of Economics and Statistics, 70, 224-235. 
[27] Lundberg, S. and R.A. Pollak (1993), "Separate Spheres Bargaining and the Marriage Market", Journal of Political Economy, 101, 988-1011.

[28] Lundberg, S. and R.A. Pollak (1994), "Non-cooperative Bargaining Models of Marriage", American Economic Review Papers and Proceedings, 84, 132-137.

[29] Manser M. and M. Brown (1980), "Marriage and Household Decision Making: a Bargaining Analysis", International Economic Review, 21, 31-44.

[30] McElroy, M.B. and M.J. Horney (1981), "Nash Bargained Household Decisions", International Economic Review, 22, 333-349.

[31] Mroz, T. A. (1987), “The Sensitivity of an Empirical Model of Married Women's Hours of Work to Economic and Statistical Assumptions", Econometrica, 55, 765799.

[32] Parkman, A. M. (1992), "Unilateral Divorce and Labor-Force Participation Rate of Married Women, Revisited", American Economic Review, 82, 671-678.

[33] Peters, E.H. (1986), "Marriage and Divorce: Informational Constraints and Private Contracting", American Economic Review, 76, 437-454.

[34] Rubalcava, L., and D. Thomas (2000), "Family Bargaining and Welfare", Mimeo $R A N D$, UCLA.

[35] Stevenson, B. and J. Wolfers (2000), "Til Death Do Us Part: Effects of Divorce Laws on Suicide, Domestic Violence and Spousal Murder", mimeo, Harvard University.

[36] Stern, N. (1986), "On the Specification of Labour Supply Functions", in Blundell R. and I. Walker (eds.), Unemployment, Search and Labour Supply, Cambridge: Cambridge University Press.

[37] Thomas, D. (1990), "Intra-Household Resource Allocation: An Inferential Approach", Journal of Human Resources, 25, 635-664.

[38] Thomas, D., Contreras, D. and E. Frankenberg (1997). "Child Health and the Distribution of Household Resources at Marriage." Mimeo RAND, UCLA.

[39] Udry, C. (1996), "Gender, Agricultural Production, and the Theory of Household", Journal of Political Economy, 1010-1046. 
TABLE 1

DESCRIPTIVE STATISTICS

\begin{tabular}{|c|c|c|c|c|c|c|c|c|}
\hline & \multicolumn{4}{|c|}{ Women } & \multicolumn{4}{|c|}{ Men } \\
\hline & Mean & $\begin{array}{l}\text { Std. } \\
\text { Dev. }\end{array}$ & Min. & Max. & Mean & $\begin{array}{l}\text { Std. } \\
\text { Dev. }\end{array}$ & Min. & Max. \\
\hline Hours of work & 1741 & 570.69 & 500 & 5120 & 2235 & 635.48 & 88 & 5824 \\
\hline Log-wage & 2.04 & 0.69 & -2.30 & 4.07 & 2.47 & 0.61 & -0.26 & 4.61 \\
\hline Age & 37.77 & 7.74 & 21 & 60 & 40.62 & 7.82 & 30 & 60 \\
\hline Schooling ${ }^{\star}$ & 5.17 & 1.48 & 1 & 8 & 5.25 & 1.64 & 1 & 8 \\
\hline White & 0.75 & & & & 0.75 & & & \\
\hline \multirow[t]{3}{*}{ Black } & 0.23 & & & & 0.23 & & & \\
\hline & \multicolumn{8}{|c|}{ Family Characteristics } \\
\hline & & & Means & $\begin{array}{l}\text { Std. } \\
\text { Dev. }\end{array}$ & Min & Max & & \\
\hline Children $(\leq 6)$ & & & 0.33 & 0.62 & 0 & 3 & & \\
\hline Children (7-17) & & & 0.97 & 1.07 & 0 & 6 & & \\
\hline \multirow[t]{3}{*}{ Nonlabor Income } & & & 8068.80 & 24197.42 & -113984.76 & 344804.75 & & \\
\hline & \multicolumn{8}{|c|}{ Marriage Market } \\
\hline & & & Means & $\begin{array}{l}\text { Std. } \\
\text { Dev. }\end{array}$ & Min & Max & & \\
\hline Sex Ratio (White) & & & 0.49 & 0.01 & 0.46 & 0.57 & & \\
\hline Sex Ratio (Black) & & & 0.46 & 0.02 & 0.41 & 0.56 & & \\
\hline \multicolumn{9}{|l|}{ Divorce Laws } \\
\hline Property Division (Community=1) & & & 0.04 & & 0 & 1 & & \\
\hline Mutual/Unilateral (Mutual=1) & & & 0.22 & & 0 & 1 & & \\
\hline Enforcement (Court payment=1) & & & 0.75 & & 0 & 1 & & \\
\hline Spousal Interest (Degree as asset $=1$ ) & & & 0.54 & & 0 & 1 & & \\
\hline Divorce Laws Index & & & 2.48 & 0.88 & 1 & 4 & & \\
\hline
\end{tabular}

Note: The education variables follow the 1989 coding. Thus, for example, a value of 4 corresponds to 12 grades and no further training, whereas a value of 5 corresponds to 12 grades plus nonacademic training. 
TABLE 2

GMM PARAMETER ESTIMATES

HOURS/1000

\begin{tabular}{|c|c|c|c|c|c|c|c|c|c|}
\hline & \multicolumn{2}{|c|}{$\begin{array}{l}\text { Unrestricted } \\
\text { Model With } \\
\text { Divorce Law } \\
\text { Dummies }\end{array}$} & \multicolumn{2}{|c|}{$\begin{array}{c}\text { Unrestricted } \\
\text { Model With } \\
\text { Aggregated } \\
\text { Law Dummies }\end{array}$} & \multicolumn{2}{|c|}{$\begin{array}{c}\text { General } \\
\text { Collective } \\
\text { Model }\end{array}$} & \multicolumn{2}{|c|}{$\begin{array}{c}\text { Collective } \\
\text { Model With } \\
\text { Caring }\end{array}$} & $\begin{array}{c}\text { Sharing } \\
\text { Rule } \\
\text { With Caring }\end{array}$ \\
\hline & Wives & Husbands & Wives & Husbands & Wives & Husbands & Wives & Husbands & \\
\hline $\log \omega_{f}$ & $\begin{array}{c}1.409 \\
(0.346)\end{array}$ & $\begin{array}{l}-0.810 \\
(0.321)\end{array}$ & $\begin{array}{c}1.427 \\
(0.340)\end{array}$ & $\begin{array}{l}-0.756 \\
(0.323)\end{array}$ & $\begin{array}{c}1.427 \\
(0.340)\end{array}$ & $\begin{array}{l}-0.760 \\
(0.322)\end{array}$ & $\begin{array}{c}0.873 \\
(0.289)\end{array}$ & $\begin{array}{l}-1.056 \\
(0.315)\end{array}$ & $\begin{array}{l}-56.638 \\
(29.524)\end{array}$ \\
\hline $\log \omega_{h}$ & $\begin{array}{c}0.782 \\
(0.296)\end{array}$ & $\begin{array}{l}-0.597 \\
(0.287)\end{array}$ & $\begin{array}{c}0.749 \\
(0.296)\end{array}$ & $\begin{array}{l}-0.564 \\
(0.288)\end{array}$ & $\begin{array}{c}0.748 \\
(0.296)\end{array}$ & $\begin{array}{l}-0.568 \\
(0.288)\end{array}$ & $\begin{array}{c}0.271 \\
(0.258)\end{array}$ & $\begin{array}{l}-0.827 \\
(0.273)\end{array}$ & $\begin{array}{l}-25.346 \\
(22.543)\end{array}$ \\
\hline $\log \omega_{f} \times \log \omega_{h}$ & $\begin{array}{l}-0.440 \\
(0.126)\end{array}$ & $\begin{array}{c}0.273 \\
(0.123)\end{array}$ & $\begin{array}{l}-0.433 \\
(0.125)\end{array}$ & $\begin{array}{c}0.255 \\
(0.124)\end{array}$ & $\begin{array}{l}-0.433 \\
(0.125)\end{array}$ & $\begin{array}{c}0.257 \\
(0.123)\end{array}$ & $\begin{array}{l}-0.215 \\
(0.104)\end{array}$ & $\begin{array}{c}0.374 \\
(0.119)\end{array}$ & $\begin{array}{c}20.063 \\
(10.744)\end{array}$ \\
\hline $\begin{array}{l}\text { Nonlabor } \\
\text { Income/1000 }\end{array}$ & $\begin{array}{l}-0.009 \\
(0.004)\end{array}$ & $\begin{array}{l}-0.006 \\
(0.004)\end{array}$ & $\begin{array}{l}-0.008 \\
(0.003)\end{array}$ & $\begin{array}{l}-0.006 \\
(0.004)\end{array}$ & $\begin{array}{l}-0.008 \\
(0.003)\end{array}$ & $\begin{array}{l}-0.006 \\
(0.004)\end{array}$ & $\begin{array}{l}-0.007 \\
(0.003)\end{array}$ & $\begin{array}{l}-0.006 \\
(0.004)\end{array}$ & $\begin{array}{c}0.698 \\
(0.170)\end{array}$ \\
\hline Sex Ratio & $\begin{array}{l}-1.796 \\
(0.965)\end{array}$ & $\begin{array}{c}4.549 \\
(1.177)\end{array}$ & $\begin{array}{l}-2.143 \\
(0.956)\end{array}$ & $\begin{array}{c}4.379 \\
(1.139)\end{array}$ & $\begin{array}{l}-2.283 \\
(0.700)\end{array}$ & $\begin{array}{c}4.267 \\
(1.024)\end{array}$ & $\begin{array}{l}-2.314 \\
(0.727)\end{array}$ & $\begin{array}{c}4.034 \\
(1.032)\end{array}$ & $\begin{array}{c}216.280 \\
(88.221)\end{array}$ \\
\hline Divorce Laws Index & & & $\begin{array}{l}-45.685 \\
(14.136)\end{array}$ & $\begin{array}{c}80.672 \\
(15.529)\end{array}$ & $\begin{array}{l}-43.994 \\
(11.769)\end{array}$ & $\begin{array}{c}81.894 \\
(14.337)\end{array}$ & $\begin{array}{l}-46.004 \\
(12.579)\end{array}$ & $\begin{array}{c}79.733 \\
(14.679)\end{array}$ & $\begin{array}{c}4309.954 \\
(1713.692)\end{array}$ \\
\hline $\begin{array}{l}\text { Divorce Laws } \\
\text { Property Division } \\
\text { (Community=1) } \\
\text { Mutual/Unilateral } \\
\text { (Mutual }=1) \\
\text { Enforcement } \\
\text { (Court payment=1) } \\
\text { Spousal Interest } \\
\text { (Degree as asset=1) }\end{array}$ & $\begin{array}{c}-0.102 \\
(0.084) \\
-0.117 \\
(0.050) \\
-0.050 \\
(0.036) \\
0.003 \\
(0.029)\end{array}$ & $\begin{array}{c}0.047 \\
(0.082) \\
0.022 \\
(0.053) \\
0.091 \\
(0.035) \\
0.112 \\
(0.027)\end{array}$ & & & & & & & \\
\hline Intercept & $\begin{array}{c}1.174 \\
(0.849)\end{array}$ & $\begin{array}{c}1.102 \\
(0.941)\end{array}$ & $\begin{array}{c}1.326 \\
(0.832)\end{array}$ & $\begin{array}{c}1.071 \\
(0.927)\end{array}$ & $\begin{array}{c}1.391 \\
(0.777)\end{array}$ & $\begin{array}{c}1.134 \\
(0.883)\end{array}$ & $\begin{array}{c}2.720 \\
(0.570)\end{array}$ & $\begin{array}{c}1.970 \\
(0.914)\end{array}$ & \\
\hline Children $(\leq 6)$ & $\begin{array}{l}-0.539 \\
(0.158)\end{array}$ & $\begin{array}{c}0.126 \\
(0.112)\end{array}$ & $\begin{array}{l}-0.510 \\
(0.155)\end{array}$ & $\begin{array}{c}0.129 \\
(0.112)\end{array}$ & $\begin{array}{l}-0.512 \\
(0.155)\end{array}$ & $\begin{array}{c}0.127 \\
(0.111)\end{array}$ & $\begin{array}{l}-0.592 \\
(0.151)\end{array}$ & $\begin{array}{c}0.092 \\
(0.112)\end{array}$ & \\
\hline Children (7-17) & $\begin{array}{l}-0.098 \\
(0.039)\end{array}$ & $\begin{array}{c}0.036 \\
(0.038)\end{array}$ & $\begin{array}{l}-0.087 \\
(0.037)\end{array}$ & $\begin{array}{c}0.041 \\
(0.037)\end{array}$ & $\begin{array}{l}-0.087 \\
(0.037)\end{array}$ & $\begin{array}{c}0.041 \\
(0.037)\end{array}$ & $\begin{array}{l}-0.098 \\
(0.037)\end{array}$ & $\begin{array}{c}0.031 \\
(0.038)\end{array}$ & \\
\hline Education & $\begin{array}{l}-0.018 \\
(0.018)\end{array}$ & $\begin{array}{c}0.036 \\
(0.012)\end{array}$ & $\begin{array}{l}-0.023 \\
(0.018)\end{array}$ & $\begin{array}{c}0.036 \\
(0.012)\end{array}$ & $\begin{array}{l}-0.022 \\
(0.018)\end{array}$ & $\begin{array}{c}0.036 \\
(0.012)\end{array}$ & $\begin{array}{l}-0.019 \\
(0.018)\end{array}$ & $\begin{array}{c}0.037 \\
(0.012)\end{array}$ & \\
\hline Age & $\begin{array}{l}-0.128 \\
(0.048)\end{array}$ & $\begin{array}{c}0.064 \\
(0.042)\end{array}$ & $\begin{array}{l}-0.130 \\
(0.047)\end{array}$ & $\begin{array}{c}0.065 \\
(0.042)\end{array}$ & $\begin{array}{l}-0.131 \\
(0.046)\end{array}$ & $\begin{array}{c}0.064 \\
(0.042)\end{array}$ & $\begin{array}{l}-0.160 \\
(0.045)\end{array}$ & $\begin{array}{c}0.047 \\
(0.043)\end{array}$ & \\
\hline White & $\begin{array}{l}-0.017 \\
(0.049)\end{array}$ & $\begin{array}{l}-0.021 \\
(0.051)\end{array}$ & $\begin{array}{l}-0.010 \\
(0.049)\end{array}$ & $\begin{array}{l}-0.015 \\
(0.051)\end{array}$ & $\begin{array}{l}-0.005 \\
(0.043)\end{array}$ & $\begin{array}{l}-0.011 \\
(0.048)\end{array}$ & $\begin{array}{l}-0.018 \\
(0.044)\end{array}$ & $\begin{array}{l}-0.013 \\
(0.047)\end{array}$ & \\
\hline $\begin{array}{l}\text { Value of Function } \\
\text { Newey-West Test }\end{array}$ & & 902 & & 473 & 2 & $\begin{array}{l}497 \\
24\end{array}$ & & $\begin{array}{l}057 \\
584\end{array}$ & \\
\hline
\end{tabular}

Notes: - Asymptotic standard errors in parentheses.

- Instruments: Second order polynomial in age and education (M-F), Father Education (M-F), White (M-F),Spanish (M-F), City size (3 dummies),

North-East, North-Central, West, Protestant (M-F), Jewish (M-F), Catholic (M-F),Sex ratio, Divorce Laws.

- The parameters of the sharing rule are divided by 1,000 (except the one associated with nonlabor income).

- Each regression includes three region dummies (North East, North Central and West). 
TABLE 3

PARAMETER EstimateS - Singles

HOURS/1000

\begin{tabular}{lcc|cc}
\hline \hline & \multicolumn{2}{c}{ OLS } & \multicolumn{2}{c}{ GMM } \\
\cline { 2 - 5 } & Wowen & Men & Wowen & Men \\
\hline $\log \omega$ & -0.036 & -0.040 & -0.177 & 0.171 \\
& $(0.049)$ & $(0.048)$ & $(0.253)$ & $(0.207)$ \\
Nonlabor Income (/1000) & -0.001 & -0.001 & -0.001 & -0.003 \\
& $(0.001)$ & $(0.001)$ & $(0.004)$ & $(0.002)$ \\
Sex Ratio & 4.187 & 1.121 & 5.857 & 0.695 \\
& $(2.569)$ & $(2.070)$ & $(2.819)$ & $(2.488)$ \\
Divorce Laws Index & -0.018 & 0.015 & -0.152 & -0.025 \\
& $(0.039)$ & $(0.034)$ & $(0.160)$ & $(0.118)$ \\
\hline Intercept & -0.374 & 1.186 & -0.739 & 1.405 \\
& $(1.243)$ & $(1.020)$ & $(1.294)$ & $(1.137)$ \\
Education & 0.077 & 0.038 & 0.095 & 0.000 \\
& $(0.020)$ & $(0.021)$ & $(0.035)$ & $(0.045)$ \\
Age & 0.052 & -0.015 & 0.079 & -0.047 \\
& $(0.038)$ & $(0.030)$ & $(0.062)$ & $(0.036)$ \\
White & 0.123 & 0.182 & 0.111 & 0.206 \\
& $(0.111)$ & $(0.089)$ & $(0.166)$ & $(0.110)$ \\
North East & -0.083 & -0.052 & -0.094 & -0.114 \\
& $(0.104)$ & $(0.082)$ & $(0.123)$ & $(0.111)$ \\
North Central & -0.202 & 0.038 & -0.193 & 0.015 \\
& $(0.078)$ & $(0.075)$ & $(0.081)$ & $(0.080)$ \\
West & -0.243 & -0.166 & -0.184 & -0.146 \\
& $(0.101)$ & $(0.092)$ & $(0.121)$ & $(0.117)$ \\
\hline \hline Value of Function & \multicolumn{3}{c}{4.470} & 9.591 \\
Number of Observations & 572 & 498 & 572 & 498 \\
\hline & \multicolumn{3}{c}{} \\
\hline
\end{tabular}


TABLE 4

SHARING RULE AND Elasticities

\begin{tabular}{|c|c|c|c|c|c|c|c|c|c|c|}
\hline \multirow{3}{*}{ Variable } & \multicolumn{2}{|c|}{ SHARING RULE } & \multicolumn{8}{|c|}{ ELASTICITIES } \\
\hline & \multirow[b]{2}{*}{ Coefficients } & \multirow[b]{2}{*}{$\frac{\partial \phi}{\partial \text { Variable }}^{\dagger}$} & \multicolumn{2}{|c|}{$\begin{array}{l}\text { Unrestricted } \\
\text { Model }\end{array}$} & \multicolumn{2}{|c|}{$\begin{array}{c}\text { General } \\
\text { Collective } \\
\text { Model }\end{array}$} & \multicolumn{2}{|c|}{$\begin{array}{l}\text { Collective } \\
\text { Model With } \\
\text { Caring }\end{array}$} & \multicolumn{2}{|c|}{$\begin{array}{l}\text { Conditional } \\
\text { on } \phi(\cdot)\end{array}$} \\
\hline & & & Wives & Husbands & Wives & Husbands & Wives & Husbands & Wives & Husbands \\
\hline $\log \omega_{f}$ & $\begin{array}{l}-56.638 \\
(29.524)\end{array}$ & $\begin{array}{l}-1634.357 \\
(1007.120)\end{array}$ & $\begin{array}{c}0.234 \\
(0.083)\end{array}$ & $\begin{array}{l}-0.073 \\
(0.037)\end{array}$ & $\begin{array}{c}0.227 \\
(0.084)\end{array}$ & $\begin{array}{l}-0.079 \\
(0.038)\end{array}$ & $\begin{array}{c}0.235 \\
(0.084)\end{array}$ & $\begin{array}{l}-0.073 \\
(0.038)\end{array}$ & $\begin{array}{c}0.178 \\
(0.090)\end{array}$ & \\
\hline $\log \omega_{h}$ & $\begin{array}{l}-25.346 \\
(22.543)\end{array}$ & $\begin{array}{c}600.442 \\
(643.569)\end{array}$ & $\begin{array}{l}-0.074 \\
(0.069)\end{array}$ & $\begin{array}{l}-0.023 \\
(0.060)\end{array}$ & $\begin{array}{l}-0.103 \\
(0.071)\end{array}$ & $\begin{array}{l}-0.031 \\
(0.057)\end{array}$ & $\begin{array}{l}-0.075 \\
(0.071)\end{array}$ & $\begin{array}{l}-0.022 \\
(0.057)\end{array}$ & & $\begin{array}{l}-0.138 \\
(0.065)\end{array}$ \\
\hline $\log \omega_{f} \times \log \omega_{h}$ & $\begin{array}{c}20.063 \\
(10.744)\end{array}$ & & & & & & & & & \\
\hline Nonlabor Income & $\begin{array}{c}0.698 \\
(0.170)\end{array}$ & $\begin{array}{c}0.698 \\
(0.170)\end{array}$ & $\begin{array}{l}-0.040 \\
(0.017)\end{array}$ & $\begin{array}{l}-0.030 \\
(0.017)\end{array}$ & $\begin{array}{l}-0.039 \\
(0.018)\end{array}$ & $\begin{array}{l}-0.028 \\
(0.018)\end{array}$ & $\begin{array}{l}-0.040 \\
(0.018)\end{array}$ & $\begin{array}{l}-0.030 \\
(0.018)\end{array}$ & & \\
\hline Sex Ratio & $\begin{array}{l}216.280 \\
(88.221)\end{array}$ & $\begin{array}{c}2162.795^{\ddagger} \\
(882.210)\end{array}$ & & & & & & & & \\
\hline Divorce Laws & $\begin{array}{c}4.310 \\
(1.714)\end{array}$ & $\begin{array}{c}4309.954^{\star} \\
(1713.692)\end{array}$ & & & & & & & & \\
\hline
\end{tabular}

Notes: Asymptotic standard errors in parentheses.

The derivatives are computed with respect to the $\omega_{f}$ and $\omega_{h}$, not with respect to $\log \omega_{f}$ and $\log \omega_{h}$.

$\ddagger$ This figure represents the impact of a one percentage point increase in the sex ratio.

* This figure represents the impact of a one point increase in the Divorce Iaws Index. 


\section{Liste des publications au CIRANO *}

\section{Cahiers CIRANO / CIRANO Papers (ISSN 1198-8169)}

99c-1 Les Expos, l'OSM, les universités, les hôpitaux : Le coût d'un déficit de 400000 emplois au Québec — Expos, Montréal Symphony Orchestra, Universities, Hospitals: The Cost of a 400,000-Job Shortfall in Québec / Marcel Boyer

96c-1 Peut-on créer des emplois en réglementant le temps de travail? / Robert Lacroix

95c-2 Anomalies de marché et sélection des titres au Canada / Richard Guay, Jean-François L'Her et Jean-Marc Suret

95c-1 La réglementation incitative / Marcel Boyer

94c-3 L'importance relative des gouvernements: causes, conséquences et organisations alternative / Claude Montmarquette

94c-2 Commercial Bankruptcy and Financial Reorganization in Canada / Jocelyn Martel

94c-1 Faire ou faire faire : La perspective de l'économie des organisations / Michel Patry

\section{Série Scientifique / Scientific Series (ISSN 1198-8177)}

2001s-15 Properties of Estimates of Daily GARCH Parameters Based on Intra-Day Observations / John W. Galbraith et Victoria Zinde-Walsh

2001s-14 A Ricardian Model of the Tragedy of the Commons / Pierre Lasserre et Antoine Soubeyran

2001s-13 Carbon Credits for Forests and Forest Products / Robert D. Cairns et Pierre Lasserre

2001s-12 Estimating Nonseparable Preference Specifications for Asset Market Participants / Kris Jacobs

2001s-11 Autoregression-Based Estimators for ARFIMA Models / John W. Galbraith et Victoria Zinde-Walsh

2001s-10 Heterogeneous Returns to Human Capital and Dynamic Self-Selection / Christian Belzil et Jörgen Hansen

2001s-09 Return to a High School Diploma and the Decision to Drop Out: New Evidence from Canada / Daniel Parent

2001s-08 Leader and Follower: A Differential Game Model / Hassan Benchekroun et Ngo Van Long

2001s-07 Emission Taxes and Standards for an Asymmetric Oligopoly / Ngo Van Long et Antoine Soubeyran

2001s-06 Risque de modèle de volatilité / Ali Alami et Éric Renault

2001s-05 The Effect of Pay-for-Performance Contracts on Wages /Daniel Parent

\footnotetext{
* Vous pouvez consulter la liste complète des publications du CIRANO et les publications elles-mêmes sur notre site Internet à l'adresse suivante :
}

http://www.cirano.umontreal.ca/publication/documents.html 